Н. М. Малюга

\title{
СУСПІЛЬНІ МОВНІ ПРОЦЕСИ В РЕТРОСПЕКЦІЇ ЧЕРЕЗ ПРИЗМУ УКРАЇНСЬКОЇ ЛІТЕРАТУРИ
}

Малюга Н. М. Суспільні мовні процеси в ретроспекції через призму української літератури.

У статті йдеться про вплив письменників сучасної доби на суспільні мовні процеси. У художніх творах автор досліджує шляхи розв'язання проблем мовного самоусвідомлення, узаємодії особистості з поліетнічним середовищем. Проаналізовано два основні типи громадянсько-етнічної ідентичності, що набувають вираження у формі психоідеологічного тяжіння до україно- або російськомовного дискурсу.

Ключові слова: рідна мова, українська література, мовне самоусвідомлення, суспільна мовна свідомість, ідентичність.

Малюга Н. Н. Общественные языковые процессы в ретроспекции сквозь призму украинской литературы.

В статье речь идет о влиянии писателей современного периода на общественные языковые процессы. В художественных произведениях автор исследует пути решения проблем языкового самосознания, взаимодействия личности с полиэтнической средой. Проанализированы два основных типа гражданско-этнической идентичности, которые 
выражаются в форме психоидеологического тяготения к украино- или русскоязычному дискурсу.

Ключевые слова: родной язык, украинская литература, языковое самосознание, общественное языковое сознание, идентичность.

Malyuga N. M. Social language processes in the rethrospection through a prism of the Ukrainian literature.

The article presents the influence of the modern writers on the social language processes. The author investigates the ways of doing the language problem of selfconsideration in the feature compositions interaction of the person with polyethnic environment. Two main types of social-ethnic indention, which are expressed in the form of psychoideological reaching the Ukrainian or Russian discourse are also analyzed in the article.

Key words: native language, the Ukrainian literature, language selfconsideration, social language consideration, indention.

Художній світ, як і мистецький загалом, став надійним засобом збереження українськості. У більшості творів української літератури першої половини XX ст. складовими стратегії етнозбереження стали «ідейне впорядкування та скріплення національного буття, доведення власної культурної та політичної окремішності, наполегливе самопізнання» [10, 300]. Українська література нової доби містить величезний спектр гострих проблем, що об’єктивно постали у зв'язку зі змінами в духовно-культурному та громадсько-політичному житті нації.

Осмислення консолідуючої функції українського мистецького слова на зламі тисячоліть досі не було об'єктом спеціального дослідження науковців, відтак обрана тема, безперечно, є актуальною й потребує детального вивчення.

Мета нашої розвідки - проаналізувати мистецьке прочитання порушених у творах художньої літератури складних соціальних проблем мовного усвідомлення та взаємодії особистості з поліетнічним середовищем.

Українське суспільство отримало комплекс проблем на мовному грунті у спадок після розпаду Радянського Союзу, у якому здійснювалася мовна політика не на користь етнічних груп. У Радянській Украйні за показником збереження рідної мови українці посідали лише четверте (після росіян, угориів, кримських татар) місце: 87\% украӥнців послуговувалися украӥнською мовою. Натомість 98\% росіян, які прожсивали в Україні, говорили рідною мовою. Російськомовність підсилювалася суттєвою допомогою з боку 91\% (від загальної кількості всього єврейського населення Украӥни) російськомовних євреїв, 79\% (від загальної кількості грецького населення Украӥни) російськомовних греків, відповідно 67\% німців, 67\% мордвинів, 61\% корейців, 55\% білорусів, 54\% чувашів, 51\% марійців (статистичні дані наведено лише стосовно тих наџіональностей, серед яких відсоток російськомовних носї̈в перевищував 50\%). Саме изі національності в Україні виявляли найвищу асимілячію до російської мови. Украӥнську ж за рідну вважали 67\% поляків, 45\% чехів, 33\% словаків, від 6 до 11\% ичиганів, білорусів, румунів, німців і молдаванів; менше 2\% представників інших національностей. 
Другою мовою спілкування вважали 85\% чехів, 54\% поляків, 47\% євреї, 43\% словаків, 33\% росіян і т. ін. Лише 2\% росіян ідентифікували українську мову як рідну (пор.: 13\% украйнців визнавали російську мову за рідну $i$ $67 \%-3 а$ другу) [3].

Ми иілком поділяємо думку Емілії Огар, щео «нині з «парадового боку» ситуачія виглядає так: у нове тисячоліття українська мова входить у довговиборюваному почесному статусі мови держави (держави незалежної), як мова національна, друга серед слов'янських за кількістю носіїв, зі сформованим літературним стандартом, кодифікованим правописом, 3 відповідним (нехай і не надто численним) видавничим - навчальним і довідковим - забезпеченням у иарині україномовної освіти» [7].

Попри промовисті цифри статистики українська література зуміла вистояти у протистоянні з тоталітарною русифікацією, планомірним нищенням національної ідентичності. Згадаймо просякнуті ніжністю, щемом слова класика: Хочеться кожне слово помити в українській криниці, де дівчина воду брала, і поставити слова чистими рядами, щяоб незабутне вигравало в них, як сонще на Великдень, і радувало людські серия у великі і трудні часи.

Хотілось би вишити слова, мов червоні квіти на холодних рушниках, $i$ розвішати рушники в кожній хатині, аби хто на них не глянув, з якого боку не зайшов, щоб вони завжди були непорочними, як говорила колись про себе моя скорбна мати (Олександр Довженко, «Незабутнє»).

Українське письменство покликане підтримувати існування української нації як цілісності. Як пише Т. Шептицька, «попри колоніальну залежність та просторову деструкцію України, своєрідне комунікативне поле, витворене національними літераторами, постійно осмислювало проблеми, пов'язані з усталенням та ширенням національно-державницької ідеї, генерувало вищі національні цінності, утверджувало спільність мрій та прагнень українства, відстоювало національну самототожність, споконвічний спосіб життя народу та його культурний декоратив» $[10,300]$.

Письменники сучасної доби приділяють чимало уваги мовному питанню. Людина перебуває в режимі життя, на яке специфічно впливають етнічна спільнота й суспільство. Узаємодія особистості з поліетнічним «чужим» середовищем наштовхується на сукупність узаємопов'язаних різноманітних факторів, серед яких визначальними стають асимілячійноконвениійні. Протягом століть українці не мали своєї сталої державності, що охороняла б начіональні інтереси й права, регулювала суспільне життя, етнічну й духовну неущербність, це змусило націю скористатися так званим «захисним імунітетом» самозбереження:

- Де ви народилися?

- В Києві. А де ж іще?

- Але ви так добре розмовлясте по-украӥнськи.

- Знаєте, в українському середовищі багато мужчин. Більше, ніж жінок. Ну...ідіотів завжди більше, ніж ідіоток... 
- Серйозно? - з жахом запитав він.

- Цілком...

- I тільки заради иього ви заговорили по-украӥнськи?

- А хіба иъього мало? Моя сестра з боку батька взагалі заговорила мовою суахілі, як попався відповідний мужчина.

- А якою мовою ви говорите з хазяями иього дому?

- Переважно мовою національного спілкування. 3 українськими інкрустаціями.

- А з матір'ю? Чоловіком? Сином?

- Із свекрухою, - в тон йому продовжила вона, - я общаюсь суржиком. Так вона мене луче понімає і передає восени картоплю.

- Ви така прагматична?

- Ну, а то як? Почала з вами російською, то надулися, як сич. А перейшла на рідну, то й гарного вина дістали (Свгенія Кононенко «Земляки на чужині»).

У мовному питанні (як і в національному загалом) простежується практика подвійних, навіть потрійних стандартів: якщо від особи певної національності можна отримати зиск, контакт із нею бажаний, то зацікавлений у задоволенні своїх потреб мовець переходить на мову співрозмовника; якщо ж представники різних етносів, що послуговуються близькоспорідненими мовами, співіснують у паралельних вимірах або ж ситуація контакту не спричиняє чи й не передбачає позитивних наслідків, годі очікувати такої ситуативної «здачі позицій».

Англійський соціолог та націолог Ентоні Сміт називає два варіанти національної ідентичності - західну (політичну), іiі творять історична територія, політично-юридична рівність, спільна громадська культура та ідеологія, і східну (етнічну), у якій визначальною є спільне походження, родинність, рідний край, рідна мова, звичаї, традиції [4, 422].

На думку Вадима Васютинського, «у сьогоденній Україні переважають два основні типи громадянсько-етнічної ідентичності, що набувають вираження у формі психоідеологічного тяжіння до україно- або російськомовного дискурсу. В основі більш чи менш наполегливої україномовності лежить переживання й утвердження власне української ідентичності більш тривкої й усталеної на заході, менш грунтовної, але такої, що дедалі більше посилюється, - у центральних регіонах. Підставу більш чи менш принципової російськомовності становить раніше набута мішана, строката ідентичність - радянсько-російсько-українсько-регіональна» [2].

Етнокультурний конфлікт породжує відчуття роздвоєності, вимушеного або добровільного балансування між «своїм» і «чужим», причому не лише у світоглядному аспекті, індивідуальному світосприйманні, а майже на всьому культурному просторі певного етносу. Проблема мовного самоусвідомлення «сягає глибини ситуації відчуження: це ставлення дітей до своїх батьків, утрата святого чуття вітчизни, зневага до родового кореня, 
відхрещування від свого непрестижного походження, а звідси - зневага до простих людей, демонстрована зверхність над трударями, чесними, відкритими в своїх почуттях, не закомплексованими снобістськими забобонами» [1, 17]. Наприклад:

- Дають хохли! - захоплено сказав до молодого хлопчина, щуо приїхав разом з ним «Волгою». Голосно сказав, сподіваючись, мабуть, щзо його за піснею не розчують. Однак Федір Безверхий, який сидів неподалік за родинним столом, таки дочувся, примружив очі й спитав:

- А ви самі, звиняйте, звідки будете?

- О, я, папаша, здалеку, - поважливо одказав молодик. - Я з Вінниці. Тобто батьки звідти. А я корінний донбасівецьь.

- А-а...То далеко! - реготнув Федір. Це ж у вас, у Вінниці, кажуть рабий замість рябий?..

- Та ні, кажу я вам: я корінний донбасівещьь. То батьки...

- Ну, то давайте вип 'ємо за ваші краї, оскирнувся Федір. - По повному, щуоб дома не журилися, як то кажуть (Григір Тютюнник «Оддавали Катрю»).

Микола Рябчук, назвавши Украӥну «культурним уламком імперї̈» зазначив: «Цей уламок складається з ретіонів, які поки щуо на культурному рівні, крім колоніяльної «малоросійськості», мало щзо об'єднує: вони розмовляють різними мовами, - $і$ то не лише в прямому, а й, щзо гірше, в переносному значенні: послуговуються різними семіотичними системними кодами, різними історичними та культурними мітами; вони читають різні книжки, слухають різну музику, дивляться різні телепрограми, передплачують різні газети, - $і$ погано не те, щуо "різні», а те, щуо немає «тих самих», немає нічого спільного, об'єднавчого, щзо б витворювало спільний дискурс, спільний культурний код, без якого, властиво, немає повночінної нації. Поки щзо є різні регіони, різні міста і села, щуо в різні часи $і$ за різних обставин опинилися в УРСР, об'єднані більше совєтськістю, ніж українськістю. Фактично вони і досі не можуть витворити спільного культурного, ба інформаційного простору, живучи у свойх «тутешніх» світах $i$ розмовляючи якщу й не на різних мовах, то, в кожнім разі, на різних звукових частотах» [9].

У своїй монографії «Українська етнолінгвістика» Віталій Жайворонок зауважує: «Якщо нервово-психічний лад, або поведінкову ознаку етнічної спільноти, формують ландшафтні, геополітичні, господарсько-пробутові умови, то мова виступає основним способом самовираження етносу, одним iз провідних індикаторів культурного поступу. Тим самим образ етносу формує не лише універсальна система знань про нього, але і його мова як «спільна духовна енергія», бо в ній постає сама дійсність, сприйнята й позначена іiі творцем з огляду на його культурно-національний світогляд» [3, 44]. Це тонке спостереження доводять чимало прикладів із художньої літератури, наведемо один із них: Люд иієї землі увижався їм ситими дядька- 
ми, щзо жадібно дудлять самогон, по горло натовкаються варениками, з гикавкою зводять пісень про забуте, примарне минуле своїх далеких прадідів, по-хуторянському сентиментально рюмсають на строкате иитво сорочки, під якою ховається зледащуіле серцее, щзо найвищуа його мрія так «дати лиха закаблуками, щзоб дісталося й передам», а вже потім - $i$ відродити гетьманів та Запорозьку Січ... (Володимир Яворівський «Автопортрет з уяви»).

Складна геополітична ситуація, що блокувала процеси самопізнання та самоідентифікації, покликала до життя явище, яке деформує уявлення про самих себе, формує численні комплекси, руйнує повноцінну картину цілісного українського світу. Лариса Масенко пише: «Умови формування так званого совєтського народу як гомогенної лінгво-культурної спільноти на основі російської мови ставили українців перед необхідністю пристосування до панівної нації. Глибинна деформованість ситуації, яка не могла не позначитись на психічному складі українців, полягала в тому, що змушувала переходити на иншу мову спілкування не приїжджих росіян (це було б цілком природно на території України), а потребувала пристосованої до новоприбульців зміни мовної поведінки від місцевих мешканців» [6].

Українське урбаністичне середовище створює психологічно комфортні умови для російськомовної частини населення і дискомфортні для тих, хто зберігає відданість рідній мові. Говорити українською в усіх ситуаціях міських контактів означає повсякчас долати опір мовного середовища. Можна сказати, що мовно-культурна атмосфера наших міст зробила російську мовою пристосування, а українську мовою протистояння:

В переповненому залі всі люди - всі! - говорили ...тією мовою, якою він думав і говорив вдома з батьками. Невже так може бути, Господи? Не один, не троє, а-всі?! Так має бути, чом би й ні, але невже таке є насправді?! Але ж $є$... $є . .$.

Зал поплив у Пашка перед очима. Все життя він сприймав свою мову і мову своїх батьків як шуось потаємне, яке треба ховати від стороннього ока, щзоб не потривожити спокою масного людського кім'яха, щзо сопить $i$ приплямкує навкруги, i тоді все буде гаразд - ти такий, як $і$ всі, хто знає про твої ганджі? Не спаде ж комусь на думку сміятися з необрізаних нігтів, якщуо їх не видно крізь взуття і шкарпетки. Пашок звикся - иією мовою, та ще й чистою, правильною, разом можуть говорити від сили n'ять-шість осіб, та й то якщзо відразу обидва дядьки приїдуть до них додому, проїзом зі своӥх кримів та києвів. Це якась підпільна друга сигнальна система, щзо засвідчує приналежність ї̈ поодиноких носіїв не до наџії, мабуть, думає Пашок, ні, а скоріме до якоїсь підпільної організащиї, похмурої і загнаної. Ця загнаність його гнітить трохи не до блювоти (Павло Вольвач «Кляса»).

Як переконливо доводять описувані ситуації, «мова окремої людини, 3 одного боку, виступає онтологічно-комунікативним відбиттям особистіс- 
ного стрижня буття, а з другого, - генеральною лінією розвитку колективної свідомості через протиставлення світу внутрішнього світові зовнішньому, суб'єктивного об'єктивному, духовного фізичному, нематеріального матеріальному. Відбуваються складні процеси формування особистісного та етнічного “я” » $[3,43]$. Мовна особистість розвивається на певному історико-філологічному тлі, що формує іiі відповідно до стану розвитку суспільства і стану розвитку мови. Відтак «мову не можна розглядати поза контекстами - соціальним, історико-культурним, інтелектуальним, власне лінгвальним. Залежність від цих контекстів - універсальна характеристика високорозвиненого мислення, спрямованого на безкінечне пояснення мовними засобами окремому носієві мови (мовній особистості) глобальної конституції - світу (і ширше - космосу)» $[3,96]$. Словник фіксує типові мовні факти, тобто об'єктивує суб'єктивне.

Людмила Пархонюк образно пояснює особливості функціонування мови як суспільного феномена: «Так само, як і грошові знаки без матеріального підтвердження перетворюються просто у красиві папірці, так само у мовній системі слово - базова одиниця - в результаті семантичного спустошення <..> знецінюється і перестає бути засобом адекватного сприйняття і тим паче впливу. Тому доречніше говорити про інфляцію слова серйозну хворобу мови, викликану іiі тривалим функціонуванням у тоталітарному суспільстві» $[8,206]:-$ Ви так харашо разгувариваїте на українськом, - сказав чоловік, - щзо мені нравиться і приятно (Валерій Шевчук, «Акт 2002 р. Раз на рік. Раннім рано»).

Таке спотворене мовлення, що будується на засадах мовного безкультур'я чи навіть нігілізму, має конкретні вияви в більшості сфер використання мови всіма, за незначними винятками, верствами нашого соціуму. Низька культура мовлення простежується і на офіційному, і на побутовому рівнях користування мовою. На офіційному їі ознаками визначають «заштампованість мовлення, словоблудство, порожні фрази, надмір перифраз, тяжіння до відверто оцінної лексики - від високопафосної до лайливої. Рівень побутового спілкування характеризується намаганням позбутися знецінених слів та зворотів офіційної мови: звідси тяжіння до діалектизмів, русизмів, англіцизмів та американізмів, жаргонізмів і навіть до нецензурної лексики та матюків. Підсвідомо ці засоби розцінюються мовцями як семантично та емоційно вагомі супроти знецінених відповідників офіційної мови» [8, 206]: Приятель старанно добирає слова. Не тому, щуо Векторова мама просила. Його власна мазе у сільській школі укрмовулітературу викладає. І чим більше він вип 'є, тим старанніше добирає (Василь Слапчук «Коротка стрілка жіночого годинника»).

Звичка користуватися російською в побуті при вимушеному переході на українську у професійній діяльності породжує явище так званої «дерев'яної мови», мови, що їй бракує природності вимови, виразності, гнучкості, достатнього лексичного запасу. Пародійні рядки Олександра Ірванця 
«Як ти звучиш калиново-дубово, рідна моя українськая мова» асоціюються саме $з$ таким поширеним типом мовлення, пов'язаним з натужним внутрішнім перекладом з російської.

Нині «носії української (та україномовної) ідентичності перебувають у процесі подолання своєї вторинності і відображення перспектив позитивного утвердження ідентичності цілісної, упевненої, захищеної. Російськомовні громадяни, навпаки, опинилися в ситуації, яку більшість їх переживає як загрозу своїй ідентичності. Раніше сформована як варіант такої собі «зразкової» ідентичності, сьогодні вона наражається на різного роду переоцінки - зовнішні і внутрішні» [2].

На думку Лариси Масенко, «за допомогою транскрибування російська чи українська мова персонажа в сучасних текстах найчастіше вже сама по собі сприймається як щось агресивне (рідше як комічне). Иншомовне транскрибування виявляє, хто 3 мовців «наш», а хто «ворог», воно чітко й остаточно означує ворога в тексті, якого характеризують такі риси, як агресивність, вульгарність, варварство» [6]:

«Кацапи - вони нахабні, - здавна каже Павлів батько. - Хоч, звісно, пєнзєнскій простий мужик нам нічого не винен. I вологодський... Аби тільки дома в себе сиділи». Це точно, мабуть. Тільки ж не сидять, думає Павло. Лізуть з нудьги Нєчєрнозєм'я, щоб потім десь в Таллінні умнічать, який естониям прапор піднімати на Тауері (Павло Вольвач «Кляса»).

Менталітет породжує певний тип імперіалізму, якщо нація стає панівною в імперії $[5,420]$. Коли мова перетворюється на символ влади, вона водночас стає потужним чинником у формуванні суспільної мовної свідомості, а надто в тоталітарному й посттоталітарному суспільстві, де значення всього, що пов'язане з владою, гіпертрофоване.

Ідеологічні звички не дозволяють помітити слушності й необхідності відмови від протистояння народів, оскільки етнічні пристрасті не дають можливості вбачати в співробітництві народів користь, загальний інтерес для суспільного добробуту:

Батьки в Собаки Павлова євреї, але на себе він це не переносить, говорить, щьо батьки - це батьки, а він - це він, більше того - Собака Павлов говорить, щьо він правий. Відповідно, з батьками він не живе, говорить, що не може жити з євреями, тусується по знайомих, інколи зависає в них на тиждень-другий, ще в нього є бабуся, очевидно, не єврейка, бо в неї він теж іноді зупиняється (Сергій Жадан «Депеш Мод»).

У мові як загальнолюдському суспільному явищі простежується трихотомія: людська мова як витвір людської природи, національна мова як колективний витвір духу етносу, індивідуальне мовлення як факт породження мови кожним окремим мовцем $[4,109]$.

Сучасна художня література прищеплює необхідність, культивує потребу жити не манкуртами - без духу, без мови, а національно свідомими людьми. Історичні події зумовлюють зміну ментальних настанов, на одне 3 
чільних місць виходить прагматизм, проте не можна уявити сучасний світ поза лояльним ставленням людини до свого етносу. Осмислення духовного буття української нації в історичній ретроспективі посідає чільне місце у прозових зверненнях літераторів.

\section{Література}

1. Аврахов Т. Поліфункціональність художньої деталі у творчості Григора Тютюнника / Тарас Аврахов // Українська мова та література в школі. - 1989. - №8. - С.16-22.

2. Васютинський В. Самовизначення мовних спільнот в сучасній Україні : між ідеологією і мораллю [Електронний ресурс] / Вадим Васютинський // Український центр політичного менеджменту. - 2009. - №2. - Режим доступу до журн.: www.politik.org.ua/vid/magcontent.

3. Воловина О. Українська мова в Україні: матірня мова за національністю і мовою навчання / О.Воловина // Про український правопис і проблеми мови / Відп. ред. Л. Онишкевич. - Нью-Йорк - Львів, 1997. - С. 210-212.

4. Жайворонок В. В. Українська етнолінгвістика: Нариси: Навч. посіб. для студ. вищ. навч. закл. / Віталій Вікторович Жайворонок - К.: Довіра, 2007. - 262 с.

5. Іванишин М. Теорія національної ідентичності в постколоніальний період / Мирослава Іванишин // Література. Фольклор. Проблеми поетики : зб. наук. праць. - Вип. 25 / Редкол.: А. В. Козлов (відп. ред.) та ін. - К.: Акцент, 2006. C. $418-426$.

6. Масенко Л. Мовна поведінка особистости у ситуації білінгвізму. Питання мовної стійкости [Електронний ресурс] / Лариса Масенко // Незалежний культурологічний часопис. - 2004. - №35. - Режим доступу до журн. : www.ji.lviv.ua/n35texts/masenko - bilingv.htm.

7. Огар Е. Українська мова в сучасній мовній ситуації в Україні: соціолінгвістичний та етнокультурний аспект [Електронний ресурс] / Емілія Огар // Портал українця. 2005. - 11 листопада. - Режим доступу до журн.: http:/www.vox.com.ua/data/2005/11/11.

8. Пархонюк Л. Соціально-історичні аспекти культури української мови / Людмила Пархонюк // Українська мова: з минулого в майбутнє. - К.: НАН України, 1998. - С.205-206.

9. Рябчук М. У пошуках «українського Маркеса». До підсумків літературного року / Микола Рябчук // Критика. - 1998. - №1 (3). - С.7.

10. Шептицька Т. Трагедія національного розбрату в українській літературі першої половини XX століття / Тетяна Шептицька // Література. Фольклор. Проблеми поетики : зб. наук. праць. - Вип. 27. - Ч. 1 / Редкол.: А. В. Козлов (відп. ред.) та ін. - К.: Акцент, 2007. - С. 300-308. 